\title{
DIE TERSIÊRE OPVOEDINGSTAAK VAN DIE VERPLEEGKUNDIGE
}

\author{
deur \\ Die Doserende Personeel \\ verbonde aan die Departement Verpleegkunde, Universiteit van Wes-Kaapland
}

\begin{abstract}
SUMMARY
In modern times emphasis is increasingly laid on the changing circumstances of health services in the Republic of South Africa as well as on the multifaceted role which the professional personnel have to play at medical, nursing and paramedical levels. The nurse-educationist is required to teach in accordance with current philosophy and aims of the educational institutions to which she is attached. Gone are the days when the tutor qualified as a good lecturer by virtue of her extensive scientific experience and insights. Large modern tertiary institutions and progress in the educational field have so changed the picture that the training of tutors today has become a specialised task.
\end{abstract}

\section{INLEIDING}

$\mathbf{I}^{\mathrm{n}}$ toenemende mate word daar in die huidige tydvak klem gelê op die veranderende omstandighede van die gesondheidsdienste in die Republiek van Suid-Afrika asook die veelfasettige rolle wat deur die professionele personeel op geneeskundige-, verpleegkundige- en paramediese vlakke vervul moet word. Van die verpleegopvoedkundige word vereis om onderrig te gee in ooreenstemming met die bestaande fïlosofie en doelstellings van die opvoedkundige inrigting waaraan sy verbonde is. Die tyd is verby dat die dosent op grond van haar omvattende vakwetenskaplike ondervinding en insigte kwalifiseer vir goeie doseerwerk. Die groot moderne tersiêre instellings en die vooruitgang op opvoedkundige gebied het die toestand van sake so verander dat die opleiding van dosente vandag 'n gespesialiseerde taak is.

Dit is noodsaaklik dat dosente die doelstellings en filosofie van dic opvoedkundige instelling waaraan hulle verbonde is, sorgvuldig moet bestudeer ten einde te kan vasstel of sy persoonlik kan funksioneer in ooreenstemming daarmee. Daar bestaan bewyse dat gebrek aan kennis ten opsigte van die verwagtings van die inrigting dikwels verantwoordelik is vir die wyse waarop dosente hul verantwoordelikhede ontduik.

In die tersiêre onderwys word daar van die beginsel uitgegaan dal daar slegs volwassenes by die leersituasie betrokke is. Soms is hierdie sogenaamde volwassene egtel nog baie onvolwasse in sy uitkyk op die lewe en mag sy verwagtings en doelwitte hemelsbreed verskil van die van die dosent. Dit is dus 'n uiters moeilike taak wat aan die verpleegopvoeder opgedra word om 'n volwasse, volwaardige ryp persoonlikheid te help vorm wat uiteindelik 'n aanwins vir sy gemeenskap sal wees.

'n Ander faktor wat beslis ' $n$ remmende uitwerking het op die vervolmaking van die taak van die verpleegkundige is dat sy nie betrokke is by die basiese pedagogiese vorming van die student nie, maar dat sy 'n leidende rol moet vervul binne die raamwerk van volwasse-opvoeding. "The education of these people is defined as the process of improving them on their society"'.

\section{DIE ROL EN TAAK VAN DIE VERPLEEGOP-} VOEDKUNDIGE

Die dosent in tersiêre onderwys se taak het verskillende dimensies. Die feit dat sy besig is om jong- en ouer volwassenes te onderrig noodsaak dat sy die beginsels van andragogiek moet verstaan en uitvoer. Slegs enkele van die belangrikste van hierdie beginsels word hier kortliks genoem. Die feit dat van studentverpleegkundiges verwag word om vanaf die aanvang van hul opleiding menselewens te beskerm, verantwoordelikhede te dra in versorging van kwesbares, siekes, belemmerdes, hulpcloses en nooddriftiges, behoort hulle nie in 'n professionele sin as adolessente behandel te word nie, terwyl hul in wese $\log$ nog adolessente is. Die dosent moet hulle as volwasse studente sien en volwasse onderwys word gekenmerk deur die bereidwilligheid van die student om persoonlike verantwoordelikheid vir sy onderwys te aanvaar. 'n Paar begrippe in verband met die andragogiese benadering is ook die volgende:- dat die volwasse student makliker leer as hulle geînteresseerd is in wat hulle doen; hulle leer meer doeltreffend as hulle skeppend kan optree en nie aan vrees, onderdrukking en verleentheid 
blootgestel word nie; hulle kry meer insig, begrip en vertroue indien hulle aan die onderrig van ander deelneem; hulle het ook ' $n$ besondere behoefte om persoonlik by die leerproses betrek te word en laastens moet hulle gehelp word om hulleself te leer ken en hul verhoudings met ander in hul persoonlike gemeenskap te begryp. Die rol van die dosent in die moderne onderwys is basies driedimensionaal van aard.

\section{Didaktiese Rol}

Hierdie rol bestaan uit die begeleiding van die professionele onvolwassene op basiese of voorgraadse vlak of na-basiese of na-graadse vlak. Dit bring mee dat die verantwoordelike dosent betrokke moet wees by beide die akademiese en nie-akademiese aktiwiteite.

Deelname aan akademiese aktiwiteite impliseer dat die dosent se eerste verantwoordelikheid geleë is in die onderrigfunksie en in aktiwiteite wat bydra tot die opvoeding van die student. Hierdie studente kan in alle ouderdomsgroepe vanaf laat adolessensie tot middeljare voorkom. Hoe hierdie studente benader en hanteer moet word sal egter nie slegs ten opsigte van ouderdom verskil nie maar ook ten opsigte van persoonlikheid, temperament, karakter en tot groot hoogte ten opsigte van die agtergrond waaruit hierdie individue afkomstig is. Hierdie faktor word dikwels buite rekening gelaat terwyl dit in werklikheid ' $n$ baie groot struikelblok in die opvoedingstaak mag wees. Sekere benaderings mag vir sekere groepe heeltemal aanvaarbaar wees terwyl andere dit as absoluut verwerplik mag beskou en dit selfs met aggressie bejeën.

Die handhawing van goeie interpersoonlike verhoudings met studente is 'n sleutelfunksie tot die suksesvolle vorming binne die beroep. Faktore wat hiertoe bydra is legio, slegs enkeles word uitgesonder:

- kennis

- filosofie

- ideale en belange -

- dissipline
- hierdie kennis moet omvattend van aard wees en moet algemene-, mense- en vakkennis insluit.

\section{dit is belangrik dat elke} mens oor 'n gesonde beroeps-, en persoonlike filosofie moet beskik ten einde 'n suksesvolle landsburger en dus ook opvoedkundige te kan wees.

die dosent moet die student voortdurend aanmoedig om belangstellings ook buite die verpleegkunde te kweek.

- waardesisteem _ die waardestelsel van die opvoeder moet van so 'n aard wees dat dit die student oortuig van die integriteit van die dosent.

gesag moet so gehandhaaf word dat dit die respek van die student afdwing.
- leierskap

'n demokratiese leierskapsrol is van groot belang vir

'n gesonde verhouding

tussen dosent en student.

- spanwerk, groepdeelname, toewyding, motivering, eerlikheid en onpartydigheid is almal faktore wal 'n groot rol speel in goeie interpersoonlike verhoudings tussen opvoeder en student.

Dit is belangrik dat verpleegkundiges aangemoedig word om die waarheid na te streef en in te skerp by hul studente. Hul moet dus ook die geleentheid gegun word om verantwoordelikheid te aanvaar vir deelname aan die akademiese aktiwiteite van die totale opvoedkundige inrigting waaraan hul verbonde is. Dosente moet nie so betrokke raak by gedetailleerde administratiewe pligte dat hulle nie hul talente kan wy en voldoende tyd het om te bestee aan hul primêre funksie, naamlik die onderrig van studente, nie.

Aan die ander kant is daar die probleem dat sommige dosente so gespesialiseerd raak op hul gebiede van onderrig dat hulle nie in staat is of bereid is om verantwoordelikheid te aanvaar vir akademiese aktiwiteite nie. Dit is dus die verantwoordelikheid van elke opvoeder om ' $n$ sin van sosiale sensitiwiteit ten opsigte van sy globale verhoudings tot die totale instelling te ontwikkel.

Alhoewel die opvoeder nie te veel gemoeid moet wees met administratiewe funksies nie, is die verpleegkundige opvoeder in mindere of meerdere mate altyd by hierdie taak betrokke. Alvorens sy die plig effektief kan uitvoer is dit nodig dat die rol en funksies van die organisasie presies bepaal word. Sodoende kan daar beter gebruik gemaak word van die mannekrag in die organisasie. Hier moet die opvoeder veral ook let op die bekwaamhede, kennis en ervaring van haar personeel en studente. Dit is so dat mense verskillend aangelê is en verskillende vlakke van vaardigheid openbaar. Afgesien hiervan bestaan daar ook die kwessie dat sommige persone kennis meer geredelik deur middel van ondervinding opdoen terwyl andere weer oor meer boekekennis beskik, dit wil sê meer akademies georiënteerd is. Hierdie toestand kan groot konflik teweegbring - 'n situasie wat groot wysheid en kennis van die leier verg.

'n Ongeskrewe verantwoordelikheid wat op alle vlakke voorkom, het te doen met die voorsiening van en erkenning en ondersteuning van studente in die uitvoering en navolging van hul kurrikulum. Indien die mens in sy totaliteit beskou word, is dit onmoontlik vir enige verpleegkundige om die massa kennis ten opsigte van die mens en sy gesondheidsbehoeftes te bemeester. Dit is dus noodsaaklik dat daar definitiewe riglyne bestaan waarvolgens die verpleegkundige haarself kan oriënteer en leiding aan studente kan gee. Om die taak van die dosent wat ' $n$ besonder vol leerplan moet dek enigsins te vergemaklik is dit noodsaaklik dat sy oor alle hulpmiddels wat sy mag benodig moet beskik en dat daar optimale fisiese fasiliteite sal bestaan waarin sy haar rol moet vervul. Vir die student wat hierdie massa kennis moet bemeester is dit nodig dat die leeraktiwiteite sal 
geskied in 'n omgewing waar begrip getoon word met haar individuele probleme en waar daar gesonde demokratiese-outokratiese student-dosent verhoudings heers.

Ten einde die geslaagdheid van die leeraanbiedinge en leerervarings te onderskraag moet daar positief en konstant gepoog word om die opvoedeling en die leerstof volgens opvoedkundig- en didaktiesgesonde strategie so te verenig dat 'n optimale graad van doelverwesenliking binne die professie bewerkstellig kan word.

Gespesialiseerde wetenskaplike kennis moet 'n integrale deel uitmaak van die pligte van die verpleegkundige dosent. Dit is slegs moontlik indien sy haarself toewy aan navorsing. Goeddeurdagte en beplande navorsing en dic publisering van artikels is 'n noodsaaklikheid vir die voortbestaan van enige beroep. Die belangrikheid hiervan moet ook by die student ingeskerp word. Daar vind voortdurend groot wetenskaplike, tegnologiese en sosiale veranderings oor die wêreld plaas. Dit is van die grootste belang dat die verpleegkundige hiermee tred hou en 'n bydrae lewer om kennis uit te brei. Navorsing moet dus voortdurend by verpleegkundiges aangemoedig word en navorsingsresultate moet in die praktyk gebruik word waar enigsins toepaslik.

Daar bestaan ' $n$ groot behoefte aan navorsing in die veld van verpleegopvoedkunde en die opvoeders wat met tersiêre onderwys van verpleegkundige studente gemoeid is, moet die navorsingsverantwoordelikheid as primêre taak beskou. Die literêre werke wat tot dusver deur akademici gelewer is, is van onskatbare waarde, maar die leemte bly steeds baie groot. Daarom word die navorsingsbydraes wat op ander toestande van die wêreld gegrond is, dikwels in die Republiek van SuidAfrika benut, terwyl die probleme inherent aan ons land wesenlik van die oorsprong van die van ander lande mag verskil.

Dit is van die grootste belang dat die tersiêre verpleegopvoeder 'n stelsel van self-evaluasie instel. Sodoende kan sy bepaal in welke opsigte van haar opvoedingstaak sy faal en dit dan so wysig dat dit aan die vereiste standaard voldoen. Studente en mededosente se menings is van groot waarde in hierdie opsig. Ten einde hierdie meningspeiling so objektief moontlik te bepaal sodat betroubare en geldige resultate verkry kan word is 'n ongetekende, onidentifiseerbare vraelys met 'n toepaslike beoordelingskaal 'n waardevolle meetinstrument.

\section{Dienslewerende $\mathrm{Rol}$}

In die breë konteks, funksioneer verpleging as 'n integrale deel van die gesondheidsdienste wat voorsien word aan 'n gemeenskap. Verpleegonderrig streef na die voorsiening van hoë kwaliteit gesondheidsdienste vir die gemeenskap en dit funksioneer ook as 'n opvoedkundige instelling deur die voorsiening van gemeenskapsdienste deur middel van verpleegopvoedkundige programme en bydraes wat gelewer word deur individuele verpleegopvoedkundiges.

Verpleegopvoedkundiges aanvaar dus verantwoordelikheid vir die daarstelling van gemeenskaplik aanvaarbare verhoudings met die gemeenskap. Die ge- meenskapsdidaktiese aspek van tersiêre onderwys lê daarin dat die dosent 'n duidelike beeld het van die plek van die tersiêre opvoedkundige inrigtings in die breër maatskaplike struktuur, met ander woorde in die sin van die instelling binne die bepaalde gemeenskap. Sekere vrae kan in hierdie verband gestel word bv. beantwoord dit aan die oorspronklike doel vir die daarstelling van die instelling? Regverdig dit die uitgawes van die belastingbetaler en die staat om daarmee voort te gaan? Lewer dit die kwaliteit van menslike produk om die beroep te beoefen soos dit moet? Word die beste gebruik gemaak van die rekrute wat die gemeenskap lewer?

Die filosofie van die meeste verpleegopvoedkundige inrigtings behels die opvoeding van die student as "totale mens", tesame met die tipe professionele opvoeding waarin hulle glo. Om hierdie filosofie uit te leef, moet die opvoedkundige inrigtings as globale eenhede funksioneer om sodoende as rolmodelle te dien. 'n Driedimensionale verantwoordelikheid, waarvan die komponente interafhanklik is van mekaar word ten opsigte van die gemeenskap aanvaar, sodat die verpleegopvoedkundige 'n geïntegreerde rol as volg vervul:

1. as individu
2. as opvoeder
3. as landsburger

Van primêre belang is die daarstelling van 'n positiewe beeld as persoon en as professionele verpleegkundige is die bepaling van plaaslike gewoontes, taboes, waardes en norme. Wanneer die eienskappe aangaande persoonlike gedrag vasgestel is, moet dien ooreenkomstig opgetree word. Die persoonlike en professionele respek van die verpleegopvoedkundige word verwerf op grond van haar gedrag soos waargeneem deur die gemeenskap.

As professionele verpleegopvoedkundige dra sy ook die verantwoordelikheid om binne die professionele kode en standaarde van die beroep te funksioneer. Dit is noodsaaklik dat hierdie beroepsmens die reels en kode moet ken sodat dit as riglyne gebruik kan word vir die uitvoering van professionele verpleegpraktyke. Die nodige veranderinge in bestaande praktyke moet aangebring kan word ooreenkomstig die sosiale veranderinge en die veranderende beroepsbehoeftes.

Een van die moeilikste en belangrikste take van die verpleegopvoeder is die van indiensopleiding. Hierdie plig berus op die beginsel dat alle kategorieë van personeel onderrig moet word op die gebied van individuele verpligtinge en met die doel om organisatoriese doelstellings via individuele doelstellings te verwesenlik. DIe omvang van hierdie faset van die taak behels dus nie studente en of personeel van gelykwaardige of eiesoortige akademiese kwalifikasies nie, maar 'n uiteenlopende diversiteit van groepe waarbinne die opvoedkundige standaarde van St. 6 tot nagraads mag varieer. Hierdie kennisverryking van die onderskeie teikengroepe moet van so 'n aard wees dat individuele personeellede dit na die samelewing kan uitdra sodat laasgenoemde tot verantwoordelike verbondenheid en betrokkenheid by gesondheidsake gemotiveer en gelei kan word. 
Die verpleegopvoedkundige dra die onvervreembare reg en verantwoordelikheid om as ' $n$ burger in ' $n$ gemeenskap te funksioneer, ongeag die professionele verpligtinge, maar dit is die manier waarop sy as burger funksioneer wat belangrik is vir professionele aanvaarbaarheid.

In die lig van dié dienslewerende faset is dit egter ook noodsaaklik dat elke dosent steeds in gedagte hou dat sy haar werkgewende inrigting verteenwoordig binne sowel as buite die gemeenskap. Die beeld wat sy uitdra na die publiek moet van so 'n aard wees dat dit nooit tot nadeel of skande van die werkgewer is nie. Per slot van sake is die werkgewende inrigting tog steeds die liggaam wat in haar materiële behoeftes voorsien en is tot groot hoogte die plek waar sy haar skeppingsdrang kan uitleef. Dit is dus vanselfsprekend dat die werkgewer geregtig is daarop, dat die diens wat deur elke individuele werker gelewer word van hoogstaande gehalte sal wees. Dikwels word hierdie feit deur werknemers tot groot hoogte geïgnoreer.

\section{STREWE TOT SELF-AKTUALISERING}

Die verpleegopvoeder het ten opsigte van haar studente 'n groot taak met betrekking tot voortgesette onderwys. Hier eindig hierdie plig egter nie, sy het ook ' $n$ verantwoordelikheid om voortdurend deur selfgeleide studie persoonlike professionele ontwikkeling en doelgerigte voortgesette leeraktiwiteite, haar eie agtergrond te ontwikkel en uit te bou. Sodoende erken sy dat om student te wees nie 'n doel op sigself is nie maar 'n dinamiese benadering tot 'n beroepsituasie op 'n lewenskontinuüm.

Hierdie essensiële self-verantwoordelikheid vloei vanuit 'n doelwit wat verder strek as dié van die organisasie waarbinne die persoon werksaam is. Dit behels die doelgerigte pogings wat die verpleegopvoeder moet aanwend om bestaande kennis en vaardighede aan te vul en om nuwe kennis en vaardighede haar eie te maak. Indien die selfontwikkelingstaak in gebreke sou bly sal die studente nooit tot volle professionele ontplooiing binne die beroep kan kom nie.

Die verbondenheid tot die voortgesette opvoedingsituasie sal ewe so sterk wees soos die lewensbeskouing en persoonlike motivering van die individu. Die beroeps- en persoonlike filosofie van die persoon wat binne die tersiêre verpleegopvoedkunde staan, het verreikende gevolge vir elke opvoedeling wat aan haar toevertrou word.

Dit is noodsaaklik dat opvoeders in die verpleegkunde verantwoordelikheid moet aanvaar binne die opvoedkundige inrigting sowel as daarbuite op plaaslike, provinsiale, nasionale en internasionale vlakke. Deelname aan verpleegkundige of nie-verpleegkundige groepe wat kan bydra tot 'n breë begrip wat verband hou met gesondheid, welsyn of opvoedkundige praktyke voorsien aan die opvoeders die geleentheid om hul agtergrondkennis op te knap en leierskapeienskappe te ontwikkel. Die uitdaging van onderrig kan nie behoorlik die hoof gebied word tensy opvoeders bereid is om die verantwoordelikheid vir hul eie ontwikkeling, ook as leiers, te aanvaar nie.
Die komponente van die leierskapsituasie word deur W.J. Kotze, 2 onderskei as die leier, die volgelinge en die taak. Op die gebied van tersiêre verpleegonderwys vind ons dieselfde toestand van sake. Die omvang van die doelstellings gekoppel aan die taak van die verpleegadministrateur. Van belang is natuurlik die aanleer van die leierskapsrol sowel as die toepaslike leierskapstyl. Laasgenoemde moet gerig wees op die verkryging van aktiewe studentedeelname - die demokratiese styl is dus die bevorderlikste metode ten opsigte van taakverwesenliking.

Douglas en Bevis ${ }^{3}$ voer die volgende as elemente aan binne die leierskapspektrum

$$
\begin{aligned}
& \text { - kommunikasie } \\
& \text { - dataverwerking } \\
& \text { - besluitneming } \\
& \text { - verandering } \\
& \text { - innovasie } \\
& \text { - menslike verhoudings }
\end{aligned}
$$

\section{ENKELE PROBLEME VAN DIE TERSIÊRE VERPLEEGOPVOEDKUNDIGE}

- die omvang van 'n vak, die omvangrykheid en diepte van alle kursusse wat die student moet bemeester en wat die dosent op sinvolle en insigtelike wyse moet aanbied

- die diversiteit van die kursussue - min ander professies indien enige moet so 'n wye spektrum van vakke dek soos in die verpleegkunde

- spesialisasie - die verpleegkundige dienste is in vergelyking met 'n dekade of twee gelede so gespesialiseerd dat enige kursus wat gevolg word spesiaal op daardie vakrigting ingestel moet wees

- gevaar van afstomping ten opsigte van praktika veral by diegene uitsluitlik verbonde aan opvoedkundige inrigtings bv. universiteite en verpleegkolleges

- gebrek aan insae en begrip ten opsigte van etniese groeperings, kulturele verskille, gebruike en normatiewe kodes van die teikengroep

- konflik binne die beroep.

\section{SLOT}

Vanuit die aard van die heterogenisiteit van die taak is die pogings om die eise van die beroep en van die samelewing die hoof te kan bied, inderdaad 'n uitdaging.

Verpleegopvoeders moet streng gekeur word en opvoedkundiges moet alles in die stryd werp om hierdie persone tot doeltreffende rolvervulling van 'n uiters boeiende faset van die professie te lei.

\footnotetext{
VERWYSINGS

1. Tobin, H.M. (Red.): Process of Siaff Develapmem, Cumponents for change. Mosby, St. Louis, 1979, p. 74 .

2 Kotec, W.J. V'erantwoordbare Leierskap in die V'erpleegadministrasie. S.A. Verpleegstersvereniging. Pretoria, 1974.

3. Douglas, L.M. \& Bevis, E.O.: Nursing Leadership in Acıon. Mosby, St. Louis, 1974.
} 